\title{
PENETRATION OF URBAN CAPITAL INTO THE PALESTINIAN COUNTRYSIDE: THE BEGINNINGS, JAFFA IN THE 1830S
}

\author{
Mahmoud Yazbak
}

University of Haifa

\section{ABSTRACT}

\begin{abstract}
Jaffa, a Palestinian port city on the eastern Mediterranean, emerged from the beginning of the $19^{\text {th }}$ century as Palestine's vibrant economic and cultural center. It attracted migrants from different Palestinian areas and from elsewhere in the Ottoman Empire, especially from Egypt, Lebanon and Syria. Capital owners in Jaffa invested heavily in citrus groves, especially the well-known "Jaffa oranges.". Also soap factories and sesame presses attracted many merchants to invest heavily in these branches. These factories depended entirely on raw material, olives and sesame, heavily produced in the country side. Big merchants and entrepreneurs (capital owners) who invested in these branches built wide and complicated economic networks in the country side to ensure steady flow of raw materials to their factories. The need for raw materials of Jaffa's capital owners pushed them to penetrate into economy of the country side making it part of the city's economic orbit. However, Jaffa's rapid development continued un-interrupted and became at the eve of Palestine's Nakba in 1948, Palestine's most important economic and cultural city. As global markets approached the Palestinian countryside through the city's merchants, the olive tree has transformed from being a source of self-sufficiency and local consumption into a marketing commodity and a source of investment, and a means of using urban capital to control the embryonic economic structure of the Palestinian countryside. The results of this transformation will be further clarified in the coming decades when large rural properties would be appropriated by the city's merchants. As a result, a new class of peasants emerged with no agricultural means of production and turned into low-skilled laborers outside the village boundaries and on the outskirts of the city.
\end{abstract}

The economic importance of Jaffa, as well as of other coastal towns in Palestine, increased rapidly from the beginning of the nineteenth century. This brought about more opportunities for investment for urban capital owners, mainly the big merchants. The penetration of urban capital into the countryside was one opportunity.

In the Jaffa hinterland, the primary mechanism for that penetration was money lending system which offered immediate cash to peasants (fellahin), against future delivery of agricultural produce. This arrangement benefitted both parties as the urban merchants accumulated considerable capital and were in need of agricultural surpluses for their factories and marketing activities, while the countryside was in constant need for cash. The merchants' capital invested or borrowed by the fellahin was guaranteed through legal contracts. As elsewhere, Jaffa's merchants preferred to 
lend money through two systems: the salam (advance purchases or deferred credits) and the bay ' wafa' (ensured sales). It was through the contracts of these two money-lending systems that much of the agricultural surpluses was appropriated by merchants from both individual peasants and entire villages. This paper discusses how the borrowing system worked and who used it and how it facilitated the penetration of urban capital into Palestine's countryside.

The expansion of commercial capital into Palestine's rural areas began long before the nineteenth century, but its effects manifested themselves most clearly after the Egyptian invasion to Bilad al-Sham (1830). ${ }^{1}$ Note that during the Egyptian rule in Palestine (1831-1840), there appeared in Jaffa's shari ' a court records (sijills) new financial transactions and commercial relations that had not been seen in the Jaffa sijills before. The most important of these transactions is the salam contracts. ${ }^{2}$

The salam contracts became common when the big urban merchants found it necessary to secure certain quantities of agricultural produce before the harvest season. At the same time, the fellabin needed cash. The principle of the salam contract was that the first party (the merchant) paid cash immediately upon the conclusion of the contract, against the promise of the second party (the fellab) to deliver the sold commodity on a later date and at the agreed price. The salam contract required that the commodity - usually crops - be delivered to the first party in kind regardless of its market price in the harvest season. According to the balance of power between the two contracting parties, it is believed that the salam contracts involved a significant proportion of (then illegal) concealed interest that guaranteed profit to the lender even if market prices fell below the expected level. ${ }^{3}$

Apparently, the merchants of Jaffa registered several salam contracts in the shari 'a court records after contracting the terms of the salam contract somewhere outside the court, usually at the merchants' office, as follows:

Al-Khawaja [honorary title of prominent merchants] Elias Al-'Asaily, the legal agent of Khawaja Qusta Israfim paid Muhammad bin Ali, from the village of Dayr Ghassanah, from the Mt. Nablus region, a sum of one thousand and five hundred qurush [cents], as salam against providing him with fifty jars of fine olive oil. The agreed-upon price of

Beshara B. Doumani, "Merchants, Socioeconomic Change and the State in Ottoman Palestine: The Nablus Region, 1800-1860" (Ph.D. Thesis, Washington , D.C., 1990), 254.

2 Beshara Doumani, I'adat iKtishaf Filastin, Ahali Jabal Nablus, 1700-1900 (Rediscovering Ottoman Palestine), (Beirut, 1988), 159-216.

3 Ibid., 166; Mahmoud Yazbak, Haifa in the Late Ottoman Period, 1864-1914: A Muslim Town in Transition (Leiden, 1998), 185. 
each jar is thirty qurush...., deferred for four months, [to be] transported to the Wahbiyya soap factory in Jaffa. The transportation fee is to be paid by the borrower and nothing by the lender... The terms of the salam become invalidated after four months from the date of signing. Jumada al-Awwal 1252/August 27, 1836. Witnesses: Haj Mahmoud Al-Azouni, Sheikh Daoud Al-Azzouni, Sheikh Amin Marrar, Mohammed Al-Qutob, Court Clerk. ${ }^{4}$

The price changes with the length of the salam period. The longer the period between the signing and the delivery of oil (in this case), the lower the price of the oil jar. This is what happened with Abdul-Razzaq, the son of the late Abdul-Dayem, the head of the village of Dayr Sudan in the al-Quds (Jerusalem) area. Abdul-Razzaq represented a group of peasants from his village and signed a salam contract with Khawaja Qustandi Israfim for 250 oil jars for 6,450 qurush to be delivered six months later. In other words, the owner paid only about 25 qurush for an oil jar. Thus, the owner of the soap factory saved 1050 qurush, equivalent to $16 \%$, thanks to the two-month delay, compared to the previous contract. It is possible to say that the $16 \%$ was the interest rate that the capital owner (the merchant) obtained from the loan to the farmer for the extension of the salam period. In order to guarantee his rights against the rest of the peasants represented by Abdul-Razzaq, the salam contract included a declaration by the peasants "that each of them personally guarantees the financial warranty for the others, and even if all missed except one, he is obliged to pay for all the others."

On several occasions, the salam contract included a statement that this is a "righteous and legitimate salam contract free of interest and meets all legal conditions." In fact, this statement was disingenuous, as proved by the salam contracts in which the price of oil changed according to the deferral period. It is clear that oil prices usually rose at the beginning of the harvest. In order to prevent competition between owners of soap factories in the high olive-picking season, they sought to secure a large amount of oil to the soap factories several months before the season. It seems that the salam contracts have become a common phenomenon in Jaffa during the Egyptian rule, designed to increase the quantities of soap exported to Egypt due to the increased demand for this commodity. However, the farmers in Jabal (Mt.) Nablus and the Jerusalem hills had long been accustomed to the salam system, before Jaffa's merchants and soap factory owners penetrated these areas. ${ }^{7}$

The prices of olive oil in the salam contracts depended on several factors, the

Sijill of Jaffa, volume 9, p. 202.

Ibid., vol. 11, p. 158.

Ibid., vol. 9, p. 215.

Doumani, I'adat iKtishaf Filastin, 167. 
most important of which was the intensity of competition among merchants to secure their oil, which led to the improvement of the farmers' bargaining terms. The farmers' demand for cash and their available network with urban merchants also played an important role in determining the price of the oil jar. While Khawaja Antoine Kassar signed a six-month salam contract with the farmers of al-Mazra'a near Jerusalem, and paid 30 qurush per jar, he paid only 22 when contracting for nine months in 1836. In the latter case, the farmers of Qarawah Bani Zayd were in need for cash immediately after the end of the harvest season. The merchant lent them the money against provision at the beginning of the next season. The farmers also agreed to deliver the produce to Jaffa. This was the lowest price we have ever seen in our documents. It seems, that the merchant was familiar with the cash crises of the village and their need for cash, which allowed him to impose such a low price. ${ }^{8}$

In the same year, Khawaja Israfim recorded a series of salam contracts, deferred for varying periods ranging from four to nine months. Interestingly, the prices of the oil jar varied from one contract to other, although the duration was similar. On the same day that Israfim signed a contract with Ahmad al-Muslih and paid 22 qurush a jar for nine months as mentioned above, he signed another contract with Hussayn al-Salakh of Dayr Ghassanah near Jerusalem and paid 25 for the same duration. ${ }^{9} \mathrm{He}$ also contracted with other farmers from the same and neighboring villages. While he paid a certain farmer 28 qurush for seven months, he paid another 27 and sometimes even 30 for the same duration. ${ }^{10}$ It is clear from these contracts that the prices of the oil jar differed not only according to the length of the term but also according to the intensity of the competition between the urban merchants, and the farmers' need for cash.

It is worth noting that all the salam contracts for olive oil contracted by Khawaja Israfim and other merchants from Jaffa during the period of the Egyptian rule were signed only with farmers from the villages of the mountains of Jerusalem. No salam contracts between merchants from Jaffa and farmers in Mt. Nablus appeared in the Jaffa sijill during the Egyptian rule, perhaps because of the social alliances in the area. The Nablus elite controlled the surrounding countryside, preventing Jaffa's merchants from penetrate this area. Conversely, the villages of the Western Jerusalem mountains located nearer Jaffa appeared to be less controlled by the interests of Jerusalem's elite. This fact has facilitated the economic penetration of Palestine's coastal merchants to those villages, linking them to a new economic system based on cash flow from Jaffa to convert olives, the most valuable product in the Palestinian mountains, into soap for domestic consumption and export.

Sijill of Jaffa, vol. 11, p. 137.

9 Ibid.

$10 \quad$ Ibid., vol. 11, p. 147, 153. 
The salam contracts in this period refer to two important issues. First, the economic base of the city of Jaffa, which has grown steadily since the end of the $18^{\text {th }}$ century, and has become in the 1830s an important productive and investment power that transcended the city limits. Second, the big merchants and capitalists, especially the owners of the soap factories and sesame presses, succeeded to penetrate rural, coastal and mountainous areas to invest in it and develop direct economic networks, as we have seen in the above examples of salam contracts. During the 1830s, the Egyptian government bought large quantities of soap, especially from the merchants of Jaffa, to supply its military requirements, which led traders to secure ample quantities of oil to provide the Egyptian army. ${ }^{11}$

The court records during that period also include salam contracts for agricultural crops other than olive oil, namely sesame and cotton. It seems that in this period the demand for sesame oil in the Egyptian market in particular increased, pushing owners of sesame presses in Jaffa to seek more salam contracts. Just as before the period of the Egyptian rule, we did not find any olive oil salam contracts in Jaffa shari a court records, this record did not contain any salam contracts for sesame. The first of these contracts appeared in 1836 and was initiated by Mohammad Abdel Fattah Damiyat, owner of a sesame oil press in Jaffa. As his name indicates, he was originally from the Egyptian port city of Damietta. In 1836, he signed four salam contracts related to sesame. These contracts included farmers from different villages in the vicinity of Jaffa and Bedouin farmers from 'Arab al-Nafi'at near Gaza. ${ }^{12}$ We also found another salam contract for sesame between Khawaja Antoine Kassar of Jaffa and farmers from the village of Qastina, near Isdud, on the coastal plain stretching from Jaffa to Gaza, an area famous for rain fed crops. Finally, a single cotton contract was signed between Khawaja Hanna Mitri and a farmer from the village of Tulkarm, northeast of Jaffa.

The terms of the salam contracts for these commodities are not different from the salam contracts relating to olive oil. The period of sesame salam contracts ranged between four to five months, usually starting in mid-May, and the commodity was delivered in September, at the end of the harvest season. All salam contracts stipulated that the agricultural product should be delivered to Jaffa at the merchant's place. Usually, transportation costs were paid by the merchant or factory owner. Owners of soap factories and sesame presses also contracted with the

\footnotetext{
11 Asad Rustum, al-Usul al-Arabiyya LiTarikh Suriyya fi Ahd Muhammad Ali Pasha, 5 vols. (Beirut, 1934), vol. 3-4, 263.

12 Sijill of Jaffa, vol. 11, pp. 148, 153, 160.
} 
owners of transport animals in order not to give the peasant an excuse to delay the transfer of their produce to Jaffa.

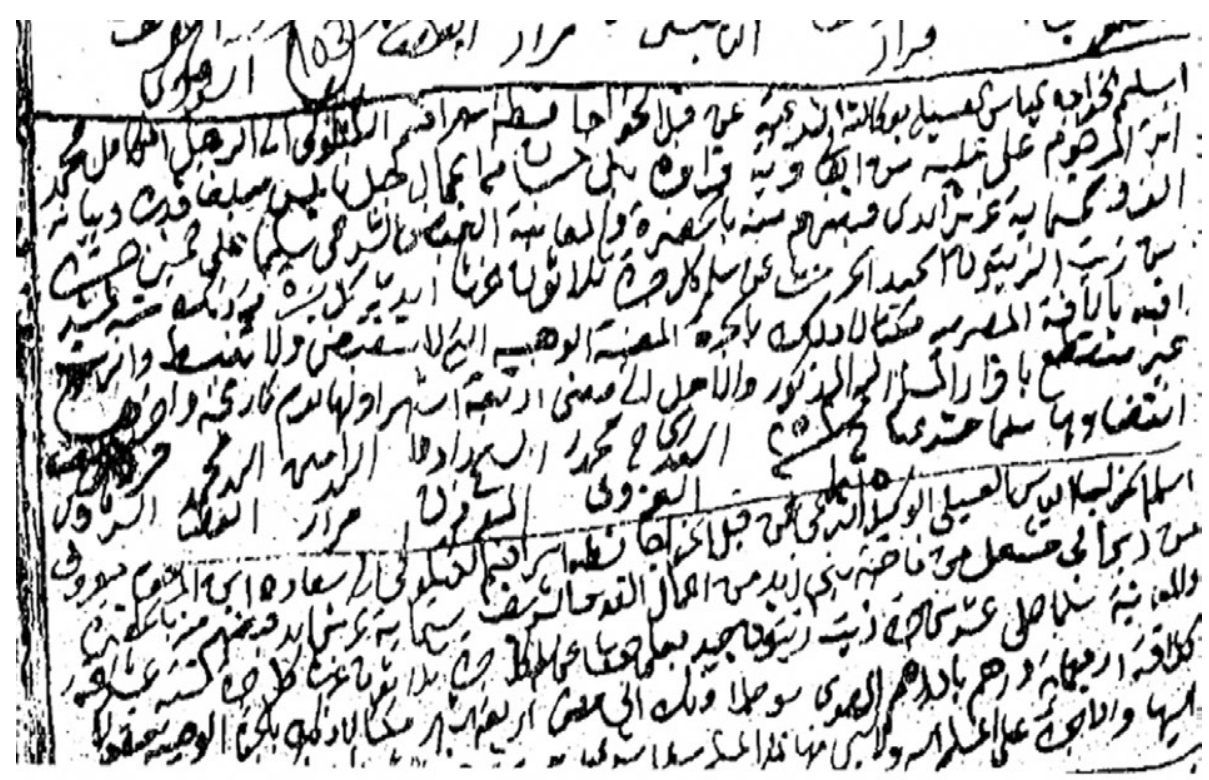

Figure 1: A Salam Olive Oil Contract

Source: Sijill of Jaffa, vol. 11, p. 148 (1836).

\section{MONEY LENDING: THE PAPERS OF KHAWAJA QUSTANDI (QUSTA) ISRAFIM}

Interest was no stranger to the Jaffa community even in simple financial transactions. A debt contract referred clearly to usury, despite the fact that everyone was aware of its illegitimacy. A case in the shari a law dealt with a loan of 700 qurush borrowed by Hussein al-Liddi from a woman called Amna al-Masri. She detailed in her lawsuit that "he owes her the amount of eight hundred qurush. Of these, seven hundred qurush are the legal debt and the eighth hundred is the interest. She asked the court to order the debtor to pay her all the amount of the loan". The defendant admitted that "she has added an extra hundred qurush on the loan for the duration, as agreed and signed to his satisfaction". Eventually, the judge ruled: "The lawsuit is unlawful and should not be heard in the court because of the plaintiff's admission that she has added to the loan pure interest [which] is illegal, and must be annulled". ${ }^{13}$ In order not to lose the interest included in salam or other forms of credit contracts, merchants sought to conceal it under different names.

\footnotetext{
Ibid., vol. 9, p. 145.
} 
In fact, the salam contracts was one of the ways of contracting between farmers and merchants of the city, which facilitated urban capital penetration in rural areas and linked their economy with that of the merchants in coastal cities. Since the 1830s, the big merchants contracted with world trade markets and met growing European and regional demand for Palestinian agricultural products such as olive oil, sesame, barley, wheat and oranges. These commodities were affected by price fluctuations due to supply and demand changes imposed by the city market, especially in Jaffa, whose economy became gradually linked to the global economy. This trade transformation produced a new class of merchants with relations to the European consuls, ensuring foreign protection. Christian merchants in particular occupied a powerful position by developing a complex network of sociopolitical and financial relations. During the period of the Egyptian rule, a certain Mikh'il Israfim became a big merchant in Jaffa. His career represents a model of social and economic change in Jaffa, especially the penetration to the Palestinian countryside.

Israfim's name was accompanied with the title Khawaja whenever it appeared on shari a court records. Khawaja is a title of respect and appreciation accompanying the names of major merchants in official documents. Khawaja Qustandi Son of Mikha il Israfim was a Catholic who came from Jerusalem and settled in Jaffa in the 1820s. He appeared to have been a wealthy man before coming to Jaffa, and to have invested his capital in various commercial ventures, and was under the protection of the consuls of Sardinia and France. Qustandi and his brother Bishara quickly managed build a wide socioeconomic network in Jaffa and its surroundings. Because of their high social status, wealth and commercial interests, each received titles of honor such as Zain 'Ashiratubu (Pride of his Community), given to only the most senior members of the Christian community.

They had a good relationship with the Governor of Jaffa sanjaq (district), Mahmoud 'Abd al-Hadi, ${ }^{14}$ brother of Husayn 'Abd al-Hadi, the Governor of Acre wilaya (province), the strongest man in Palestine during the Egyptian rule. The leadership of the 'Abd al-Hadi family was prominent in Palestine and in Mt. Nablus in particular. The Israfims' relationship with the 'Abd al-Hadis developed into a commercial and investment partnership in several fields in Jaffa, including the establishment of new stores on the beach near the port and the Sea Mosque. ${ }^{15}$ This relationship with Mahmoud 'Abd al-Hadi provided an important safety net for the investments of the Israfims, particularly in the rural areas of Jerusalem and Nablus, enabling them to secure continuous supply of olive oil to their soap factories to meet the growing Egyptian demand.

14 Ibid., vol. 10, p. 176, 270. Mahmud 'Abd al-Hadi was the mutasallim of Jaffa (1832-1834).

15 Ibid., vol. 10, p. 176. 
The salam contracts was not the only way through in which Qustandi Israfim penetrated the countryside. In his commercial dealings with the fellabin, he also used the direct lending method, with contracts imposing hidden and high interest, ensuring control over the price of olive oil and linking a large group of farmers to his economic networks. From March 15, 1837 (8 Dhu al-Hijjah 1252) and for a whole month, the registrar of the shari 'a court in Jaffa was occupied documenting and editing more than seventy legal loan contracts by Israfim. These documented the amounts lent, the interest rate, the names and villages of the farmers, and the witnesses. The following is the text of one of these loan contracts, as an example of the rest of the contracts concluded by the Khawaja with the peasants:

To the shari' a council came Saleh Al-Abed from the village of 'Atara [near Jerusalem]. He recognized and acknowledged that he was legally indebted to Khawaja Israfim the Catholic an amount of 480 qurush as a legal debt. Four hundred qurush of it is a cash debt, and the other 80 qurush is against an amber narghile, deferred to ten months from the date below. All this is ratified by Khawaja Bishara [Israfim] the legitimate agent of his brother Khawaja Qusta. The period of debt begins on mid-Dhu al-Hijja 1252 [March 22, 1837].

All of the loan contracts concluded by Khawaja Israfim expired in January or December, the season of olive picking and pressing. Although olive oil was not mentioned in these contracts and nothing was mortgaged against the loan, as was the case in the salam contracts, it was clear that the date of repayment was tied to the olive pressing season when the farmers sold their products to merchants from Jaffa, perhaps also Israfim himself.

The above loan contract poses a set of questions. How did Israfim ensure repayment? Where was the benefit hidden in this "legal loan"? Is this really a legitimate loan? What is the role of the witnesses in this contract? Usually, seven witnesses signed each of these loan contracts. In one day, ten such contracts were registered in the Jaffa court. For each of these, contractors and witnesses attended in the courtroom, meaning that the courtroom was filled with people from different social backgrounds who came to register the loan contracts of Khawaja Israfim. We can imagine a crowd of more than 100 men standing in front of the court and how this affected a small city like Jaffa in the 1830s. This crowd testified to Israfim's socioeconomic power. It is also important to imagine the logistics involved in bringing these crowds from different places to Jaffa and pay the farmers in cash. This process could not have been organized on the same day had Israfim not had agents spread in the various villages to contact the peasants and network them with the Khawaja himself. Some of the loan documents refer clearly to village elders or to sheikhs (heads) of the nahiya (subdistrict) as a borrower or as selling his products to Israfim. 
In fact, Israfim succeeded to build up his network with Palestine's rural areas through the influential rural leadership, and through them also he "secured" his loans in full and ensured its payment on time including the interest. In addition to the village dignitaries, the names of the witnesses included many of the influential religious and social personalities in Jaffa itself, attesting to Israfim's influence among the town's social elite as well.

Studying the pattern of financial lending at this period through 70 lending operations by Israfim shows that the hidden interest rate was $20 \%$ on the total amount for a period of ten months, and that the loan and the interest were paid together in one payment at the end of the loan period. ${ }^{16}$ The abovementioned loan document includes the loan details and terms, the most important of which is that the hidden interest is an integral part of the amount that the debtor undertakes to repay. The amount of the actual loan received by the debtor is referred to as "cash money" (darabim nuqud) and the interest is hidden in "the price of the amber narghile," here, or in other goods such as cloth and soap. In other words, the contractors state that the debtor bought from the lender some goods added to the amount of the loan and the borrower became indebted to the lender and repaid accordingly. The percentage of the price of goods, i.e. the interest, was $20 \%$ for ten months in all contracts concluded by Israfim, or $24 \%$ annually. Thanks to this thinly disguised ruse, the contract could be registered as legitimate, since it did not contain the explicit terms "interest" or "usury," illegal in Islamic law. The amounts in Israfim's contracts ranged between 100 and 8500 qurush, averaging 800 qurush for an average term of 9-10 months. The total capital in the seventy documents mentioned above amounted to 72,185 qurush.

The record includes 13 documents that did not specify the amount of cash loan and interest, i.e., the goods hiding the interest, as in the following example:

To the council of the shari 'a court came Muhammad al-Umar, from the people of the village of Bani Zayd of the nahiya of al-Quds alSharif. He acknowledged and confessed that he is rightfully indebted to Khawaja Qusta Israfim the Catholic an amount of 2,200 qurush against two qintars (quantity) of soap deferred to ten months from the date below. All of this was confirmed by Khawaja Elias al-Usaily, the legal agent of Khawaja Qusta. The period of delay begins on the sixteenth of Dhi-Al-Hijja of the year 1252. ${ }^{17}$

We do not know why this debt contract and twelve similar others were made this way, contrary to previous contracts that contained detailed information about

16 The lending documents are documented in the sijill of Jaffa, vol. 11. pp. 280-297.

17 Sijiil of Jaffa, vol. 11, p. 290. 
the amount of cash and the goods, i.e., interest. Interestingly enough, all these twelve contracts stipulated that the amount of debt against the soap quantity was also deferred for ten months. Whatever the case, all the debt contracts we found in the sijill involved farmers who came to Jaffa from their villages and borrowed cash from merchants in Jaffa. In other words, these farmers were no longer confined to their villages, but the city became an important part of their livelihood. This process of growing contacts between the city and countryside would have important socioeconomic and political implications in subsequent decades.

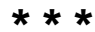

Reading other lending contracts of Qusta Israfim clarifies that he expanded his investments in the Palestinian countryside not only by money lending and crediting, as in the previous examples. Since 1838, he began purchasing agricultural lands, olive plantations and oil presses in the countryside. These last investments were done through a lending system known as bay 'wafa', whereby the debtor "sold" a piece of property to the lender equal in value to the sum borrowed plus "interest" for an agreed period of time after which the loan was repaid. This mechanism was also designed to circumvent the shari ${ }^{\prime} a$ prohibition on taking interest. In fact, the full ownership of the property was transferred to the lender and he had the right to use it fully until repayment. The bay 'wafa' contract was the most profitable contract for the lender and the most damaging to the seller, i.e., debtor. In many cases, the borrower lost what he had sold or mortgaged against the loan, because the mortgage or bay' wafa' included the source of production for the borrower. ${ }^{18}$

According to the following document, for example, the borrower sold or mortgaged all that he owned in the village's olive press, and also planted land with olive trees:

Khawaja Bishara son of Khawaja Mikha'il Israfim the Catholic, the legal agent of his brother Khawaja Qusta Israfim, bought with the money of his principal for his principal from the sellers Sulayman bin Muhammad Al-'Ais and Abdul Hamid bin Abdul Majid Al-Rawwas. Both are from the village of Kafr 'Ayn in the Bani Zayd nabiya of alQuds al-Sharif. They came to the shari' a court in Jaffa together with Khawaja Bishara, the aforementioned agent. They sold him, for his principal, Khawaja Qusta, eleven qirat [karat, a fraction] of twentyfourth of the whole, of all the [olive press] in the abovementioned village...

18 For more information about the "bay' wafa" system and its social and economic effects on Palestine, see, Mahmoud Yazbak, Haifa in the Late Ottoman Period, 185, 203-204, 217. 
They also sold him the musha ${ }^{\circ}$ (common share) of eight qirats of all the olive press located in the western side of the abovementioned village... and a piece of land in the [nearby] village of Farta which contains 160 olive trees... The price for all these is 3000 qurush... The price is paid by Khawaja Bishara, the agent of his brother with the money of his brother, to the sellers as they legally acknowledged the receipt of said amount.

Then, after the completion and conclusion of this, the buyer, Khawaja Bishara, acknowledged on behalf of his principal Khawaja Qusta that he promised the aforementioned pledgees that when they pay him or his brother the price of the abovementioned, he will return to them the sale mentioned above, as legally promised. The two sellers allowed Khawaja Qusta to use the two oil presses and olive plantations as long as the loan was not repaid in full. This is a legal permission. ${ }^{19}$

The bay' wafa' system entailed that the debtor would sell a piece of property to the lender equal in value to the amount borrowed for an agreed period of time after which the loan was discharged. The debtor became the renter of the property (usually a house or a piece of land, or both), of which the lender was now temporarily the owner, for an annual payment to latter, the rent in fact being the interest. Again, the system was designed to circumvent the religious legal prohibition on taking interest. It also entailed that debtors who proved unable to repay simply forfeited their property to the lender. ${ }^{20}$

The bay' wafa' document quoted above confirms that Jaffa's capital owners and merchants, after penetrating the rural economic structure, moved on to a new stage: effectively controlling the means of agricultural production, to become part of their wealth. As a result of the bay' wafa' contracts, many of the rural means of production moved to Khawaja Qusta's ownership and to similar other merchants in Jaffa. In this case, the judge did not hesitate, when the validity of the contract was proved, to enforce the sale. ${ }^{21}$ This shift in urban investment reflected the enormous economic changes that the Palestinian society was subjected to during the Egyptian rule.

The injection of urban capital into the countryside through credit and debt and the accompanying interest and accumulation of debt, the year-on-year transfer of this debt and the imposition of fines on arrears necessarily led to the loss of many

19 Sijill of Jaffa, vol. 11, p. 285.

20 Mahmoud Yazbak, Haifa in the Late Ottoman Period, 185.

21 See examples in the sijill of Jaffa, vol. 9, pp. 180, 182. 
farmers' means of production and livelihood even in this period preceding the Ottoman legal transformations, or Tanzimat, which were responsive to changes in the local market and world trade, such as the Land Law of 1858 and the Vilayets Law of 1864, and many other legal changes until the end of the Ottoman Empire. In the final analysis, during the reform period, the Ottoman legal system facilitated the transfer of agricultural land, i.e., the means of rural production, to the hands of local and foreign investors who turned it into a commercial commodity, sold and bought like any other. This was not permitted before the Land Law.

As we have seen above, through the bay' wafa' system, capital forces were stronger than the prevailing law. The transfer of rural property actually began during the period of Egyptian rule, i.e., twenty years before it was legally approved. The following example clarifies that for the fellahin, such contracts created a vicious circle of indebtedness:

The Shari'a council was attended by Abdul Rasul... of the people of the village of Yabrud in the vicinity of al-Quds al-Sharif and acknowledged... that he had contracted with the khawaja Bishara Israfim the Catholic, the legal agent on behalf of his brother Khawaja Qusta... and it is agreed that he is indebted the amount of 6155 qurush, and hundred jars of olive oil... And after that he bought from Khawaja Bishara the agent of his brother fifty pieces of Egyptian cloth at the price of 2025 qurush, [...] So his total debt to the Khawaja became 7388 qurush and a hundred oil jars. [...] All this debt is deferred for nine months from the date below [...]. Then came to the shari 'a court the honorable sheikh Samhan and guaranteed the amount of the debt... ${ }^{22}$

The contents of the above document clearly indicate that the debtor has not been able to repay his debts from previous years. What the debtor had to do now was renew his debt with the interest included and add compounded $20 \%$ interest on the whole amount. But the document above does not explain about the hundred oil jar pledged by the debtor. Was this part of the fine on previous debt? Or was it part of the new debt? In any case, the hundred jars of oil constituted a considerable sum, as one jar was sold in the market for 30-35 qurush.

What is important in this case is the appearance of the financial guarantor, the sheikh of the nahiya himself. As mentioned above, Khawaja Qusta's networking with powerful leaders in the Palestinian countryside facilitated the injection of his capital and secured a safety net to collect debts and later, to effectively control the means of rural production. ${ }^{23}$ In his research about Nablus, Doumani also men-

\footnotetext{
$22 \quad$ Ibid., vol. 11, p. 289.

23 The activities of khawaja Qustandi in Palestine's rural areas and its results are similar to the conclusions which Doumani have reached in Jabal Nablus. See, Doumani, I'adat iKtishaf Filastin, 192-194.
} 
tioned that in the same period, most of the merchants were not interested in owning much of the land that they could have acquired due to debtors' default. Their main concern was to keep the farmer or village under debt so that they could ensure steady supply of cheap agricultural goods. ${ }^{24}$

However, opening the doors of Palestine to the Western religious, economic and political interests during the Egyptian rule led to radical changes in Palestine's social structure and created new social elite, especially Christians, who depended on trade, money and foreign protection.

\section{BIBLIOGRAPHY}

\section{UNPUBLISHED ARCHIVAL SOURCES}

Sijill of Jaffa, volumes 9, 10, 11.

\section{LITERATURE}

Doumani, Beshara B.." Merchants, Socioeconomic Change and the State in Ottoman Palestine: The Nablus Region, 1800-1860." Ph.D. Thesis, Washington, D.C., 1990.

Doumani, Beshara. I'adat iKtishaf Filastin, Ahali Jabal Nablus, 1700-1900 [Rediscovering Ottoman Palestine]. Beirut, 1988, 159-216.

Rustum, Asad. al-Usul al-Arabiyya LiTarikh Suriyya fi Ahd Muhammad Ali Pasha, 5 vols.. Beirut, 1934, vol. 3-4.

Yazbak, Mahmoud. Haifa in the Late Ottoman Period, 1864-1914: A Muslim Town in Transition. Leiden: Brill, 1998. 